\title{
Adolescent’ Experiences Using Pornography
}

\author{
Mariyati*, Eva Zuliana, Arifianto \\ Universitas Widya Husada Semarang, Jln. Subali Raya No. 12 Krapyak Semarang Jawa Tengah, Indonesia \\ 50146 \\ *maryhamasah@gmail.com
}

\begin{abstract}
The experience of teenagers using pornography in Semarang City has greatly increased. Many teenagers don't understand what the harm use pornography harm. The impacts that occur include difficulty concentrating, not focusing while studying, daydreaming, hallucinations, increased sexual appetite with masturbation and masturbation. Adolescents become more precocious and they had sex before marriage. This study aims to explore the experiences of adolescents who access pornography at SMA Setia Budhi Semarang City. The sampling technique used purposive sampling to determine the appropriate sample, namely adolescents who accessed pornographic media for more than 2 months. This type of research is qualitative with a descriptive phenomenology approach. Obtained data saturation in the fifth participant. Data collection through in-depth interviews (in depth interviews) and field notes (field notes). Researcher's data analysis was carried out after and during the study and the validity of the data by using member checking. This study resulted in 4 themes, namely the supporting factors for adolescents in using pornography, increasing the frequency of using pornography, the response of adolescents when using pornography, and the perceived impact of using pornography. The main reason why teenagers access pornography is due to the invitation of their friends and their own desires, so that the desire to access pornography appears continuously. This results in adolescents having difficulty concentrating, learning problems, difficulty sleeping and the desire to try and imitate seen sexual behavior.
\end{abstract}

Keywords: phenomenology; pornography; teenagers

\begin{tabular}{|c|c|c|}
\hline $\begin{array}{c}\text { First Received } \\
18 \text { December } 2020\end{array}$ & $\begin{array}{c}\text { Revised } \\
24 \text { December } 2020\end{array}$ & $\begin{array}{c}\text { Accepted } \\
\text { 28 January } 2020\end{array}$ \\
\hline $\begin{array}{c}\text { Final Proof Received } \\
\text { 08 February } 2021\end{array}$ & & $\begin{array}{c}\text { Published } \\
21 \text { February } 2021\end{array}$ \\
\hline $\begin{array}{l}\text { How to cite (in APA style) } \\
\text { Mariyati, M., Zuliana, E., \& Arifiant } \\
\text { Journal of Global Health Research, 3( }\end{array}$ & $\begin{array}{l}\text { 021). Adolescent' } \\
\text { 00. https://doi.org/1 }\end{array}$ & $\begin{array}{l}\text { ces Using Pornography. Indonesian } \\
\text { lijghr.v3i1.384 }\end{array}$ \\
\hline
\end{tabular}

\section{INTRODUCTION}

The rapid advancement of technology has an impact on the lives of teenagers. The role of information technology or electronic media, especially the internet, has made the world more accessible. The internet has the ability to inform various world events continuously for 24 hours (A. Kurniawan, 2018). Current technology devices make it easy for its users to enjoy application features related to social media. Pornography in mass media includes videos and photos of women dressed in sexy or unclothed clothes, writings depicting sexual relations in various print media, sex scenes in cinema films, web videos and video player. Likewise, youtube with various pornographic shows which are mostly accessed by teenagers (Nugroho, 2016).

The study showed that print and electronic media with pornographic content have a significant influence with adolescent sexual behavior as indicated by the Sig. 0,000 or $<0.05$ (Ambarsari, 2018). According to Ibrahim et al, in 2018 the reason underlying teenagers using pornography among teenagers wants to get pleasure and increase their sexual desire. About $20 \%$ children and adolescents suffer from mental and behavioral disorders due to exposure to 
pornography (Haney, 2004). Based on the stud about Behavioral Cognitive Therapy and SelfHelp Group Therapy to Deal with Adolescent Anxiety with Pornography Addiction. These mental disorders include anxiety as much as $13 \%$, behavior disorders as much as $16 \%$ and emotional disorders as much as $6.2 \%$ which occurs at the age of 9-17 years. In addition, adolescents also experience depression, have suicidal thoughts, compulsive behavior, addiction and even criminal behavior. The more serious impacts are sexually transmitted diseases, HIV / AIDS, unwanted pregnancy and mental disorders in adolescents themselves (Yati \& Aini, 2018). The prevalence in Indonesia is $80 \%$ of internet users. According to data in Central Java, the prevalence of adolescents using pornography has increased every year. In 2017 there were $94 \%$ of teenagers and an increase in 2018 by $98 \%$. Data in the city of Semarang, the number of adolescents exposed to pornography is $34.7 \%$ (Mariyati et al., 2018). Accessing pornography is a deviant behavior, because it is expected to be the basis for making policies related to the use of social media in students as well as supporting government policies related to efforts to combat cases of sexual deviation (Siyoto et al., 2018).

The study showed more men access pornography than women, namely 78 men (65\%) and 42 women (35\%). Based on the education level of junior high school (SMP) adolescents, namely 63 people $(52.5 \%)$ and SMA (51 people $(42.5 \%)$ and there are 3 elementary school (SD) levels and college 3 people $(2.5 \%)$ (Pahlawan \& Wijayanti, 2018). There is a relationship between dating and exposure to pornography (A. Kurniawan, 2018). Since the purpose of this study to explore the experiences of adolescents using pornography, so this research used a qualitative study with a phenomenological approach. The importance of this research is to provide knowledge to adolescents about the impact using pornography and the importance of the role of parents to assist children in their development process.

\section{METHOD}

The method used in this research is a qualitative research method through a descriptive phenomenology approach. This study explores the experiences of adolescents who access pornography with the aim of learning everything related to their experiences. This study was done in June-August 2020 at SMA Setia Budhi Semarang City. The study population was adolescents who had accessed pornography, based on information from the counseling guidance teacher, there were 12 students who were recorded as having accessed pornography while at school. The sampling technique used purposive sampling, namely adolescents who had accessed at least 2 months in order to be able to tell their experiences. Data collection by in-depth interviews. In the data analysis process, data saturation was obtained in the fifth participant. Data analysis was carried out by transcribing data, identifying important statements and keywords, categorizing keywords into categories, concluding categories into meaningful themes. The study was conducted after an ethical test at the Health Research Ethics Committee with Number 05 / EC-LPPM / UWHS / I-2021.

\section{RESULTS}

\section{Characteristics of participants}

This study involved 5 participants who sharing their experiences of using pornography. The characteristics of the participants are described in table 1 . 
Table 1.

Characteristics of participants based on age, sex and religion.

\begin{tabular}{clccc}
\hline No & \multicolumn{1}{c}{ Initial } & Code & Age & Gender \\
\hline 1. & Sdr. Ah & P1 & 16 years old & Male \\
2. & Sdr. Ad & P2 & 15 years old & Male \\
3. & Sdr. Ri & P3 & 17 years old & Male \\
4. & Sdr. Sa & P4 & 16 years old & Male \\
5. & Sdr. Cin & P5 & 17 years old & Woman \\
\hline
\end{tabular}

Table 1 shows that $80 \%$ of the participants are male, the range of age is $15-17$ years, so that all participants can be concluded that they are in the adolescent development phase.

\section{Theme of Research}

This study resulted in 4 themes, namely the supporting factors for adolescents in using pornography, increasing the frequency of using pornography, the response of adolescents when using pornography, and the perceived impact of using pornography. The description of each theme is as follows:

\section{Theme 1 : Supporting Factors for Adolescent Using Pornography}

Participants said that they have known pornographic media for a long time, some have just met from their friends and some know from the advertising media or the timeline. This theme is formed from several categories and keywords as follows:

Accidentally saw porn media

"See the sexy body on the timeline, accidentally" (P1)

"When I opened my parents' cellphone, it turned out that there were pictures of one sister ..." $(P 2)$

Invite peers

"I know porn shows from my friend's father and open a porn application" (P3)

From the google application site then watch it together with friends "(P5)

Self-curiosity

"I was curious about what porn was like, then I looked for the application" (P4)

\section{Theme 2: Adolescent response when using pornography}

When using pornography, the response felt by adolescents was different. Adolescents experience unusual feelings, shock, disgust, nervousness, the blood in the body suddenly warms up, and dreams. This theme is explained by participant statements as follows:

Feelings that arise

"If you see the sexy one immediately excited, her body suddenly gets warm" (P2)

"Ahhh it's normal to see that, because now many people wear clothes that open like that" (P5) b. Imagine

"So many banyangin no- no, as I see it" (P3)

"Then imagine, for example, I was with my girlfriend, delicious like that" (P2)

"Sometimes I feel like what I watch, eventually my semen comes out" (P1)

c. Shocked and disgusting

"Wow, how come it turns out like that, I didn't expect and I was surprised that there was such a spectacle" (P4)

"Gradually disgusted myself to see that, dizzy myself" (P4) 
d. Shame and fear of sin

"If you look at having sex, it's really disgusting, like you want to throw up. And I'm embarrassed too, how come I see it, sometimes I'm afraid of sins "P5)

\section{Theme 3: Increased use to pornography}

Initially the participants were curious and joined in using pornographic content. But over time, there was a desire to access pornographic content until it became a necessity. This theme is explained by participant statements as follows:

"Participants said the situation when using pornography. Starting from the intention and the situation is safe" $(P 1)$

"If I have the opportunity to watch pornographic videos, the opportunity is if I am alone"

"If I want to see porn videos at night before going to bed and my family situation is all sleeping" (P4)

Through the Yandex website, rarely ...., maybe only 2 to 3 times a month "(P5)

\section{Theme 4: Impact of using pornography}

Pornography causes adolescents to have learning problems, lazy to socialize, have problems with their parents, change their appearance, behavior and increase their sexual needs. This is evidenced by the following participant statements:

Problems in learning

"Lack of focus on school, lazy to study .." (P1)

"I don't concentrate during lessons, if I always daydream and imagine the videos I watch" $(P 2)$

Change in appearance

"In the past, my appearance was normal ... and since I knew porn, my appearance changed a little to make it more attractive" (P1)

Lack of socialization

"I tend to close myself more and like to be at home, because the situation is very supportive" (P1)

Increased sexual activity

"I tried that with my girlfriend ..." (P2)

"I often have dirty thoughts when I see objects that lead to sexuality." (P4)

\section{DISCUSSION}

\section{Theme 1: Supporting Factors for Adolescent in Using Pornography}

The participants said that the way to access pornography from peers was to know and be invited from school friends, my friend sent me videos via Bluetooth, and via my friend's father's laptop. The study showed that the greater the negative influence of peers, the more adolescents have a tendency to behave sexually at risk. That boys are more risk of having sexual behavior than girls. Male is more aggressive, open, persistent and overt sexual behavior and find it difficult to hold back than girls. Adolescents who have low knowledge have a greater chance of having risky sexual behavior than adolescents who have high 
knowledge. The category of pornography access in Kalipare MTS X are mostly classified as rare as $72.5 \%$, while the good category was $25.7 \%$, and the category never is $1.8 \%$ (Siyoto et al., 2018).

The study about The Effect of Exposure to Pornography and Peer Media on Adolescent Sex Behavior. The Beginning of How to Access Pornography on peers from their closest friends and the environment around the teenager, including school friends, hanging out friends, and the home environment, Incidents of using pornography in online schools using learning applications and web advertisements that contain pornographic images, examples of news Finally, this teenager apparently wanted to know about pornographic images that were not supervised by her parents while studying (Pujiati \& Handayani, 2018).

Participants have explained that the initial method of using pornography is usually with school friends or close friends in their environment. That in their environment teenagers like to hang out at the patrol post with their friends and various stories to discuss how to access pornography, while school friends are one of the teenagers who know how to using pornography and then invite other friends to watch together during class breaks. The current digital era internet users increasing widely and easily. This is evidenced by more people using digital tools such as smartphones and tablet to access any information via the internet. In addition to bringing a good impact in the form of easier communication with anyone and anywhere, but it also appears the various harms are not inevitable, especially for children and young people. Advances in technology have nowadays made it easy for teens to obtain information from the mass media. Information such as this tends to be adolescent sexual problems on pilings and sexual behavior that is not responsible, such as advertising porn and porn movie very much found on the internet (Putri et al., 2017).

\section{Theme 2: Adolescent response when using pornography}

Participants said that their feelings when using pornography were undecided, daydreaming, imagining, and very curious. This study are supported by previous research that the sense of using pornography, curiosity is higher, wants to experience sex, imagines wanting to do it with their partner, afraid to access pornography caught with parents. Participants have mentioned the feelings when using pornography that the teenagers feel want to know more. Some teenagers have even more extreme imaginations, and dream of having sex with their partners (Ningsih, 2015).

The results of the interview participants said that the feeling after using pornography was that they were afraid of being caught by their parents and there was no feeling of exaggeration. The previous study about the Relationship of Religiosity with the Intensity of Using Pornography on Students of Hasyim Asy'ari Pekalongan High School. A teenager begins to care about sexual attraction and begins to feel the feeling between love and lust so that the interest and sensitivity regarding sexuality is very great. Adolescents was attracted to find and explore related to sexuality (Puspitasari et al., 2019). Pornographic sites circulating on the internet are increasingly prevalent and make it easier for a teenager to fulfill his curiosity about sexuality. That the internet can make it easier for someone to access various sites according to their wants and needs. On other side, the internet network can make it easier for a person to access information quickly, but it will have a bad impact if the internet network is used to access inappropriate sites such as pornography, causing addiction and will emerge with feelings of pleasure and satisfaction after seeing porn scenes causing adolescents. 
Participants have mentioned feelings after using pornography that there are no feelings that are very excessive and some are very excessive, when watching pornography at night they are afraid of suddenly being caught by their parents, feeling very good, the average level of teenage curiosity is higher and wants to access more pornography large.

\section{Theme 3: Increased using to pornography}

Time and situation when using pornography obtained from in-depth interviews. The results of the interview participants stated that when they access pornography via the internet, they are usually accessed when the house is quiet. The previous study about Relationship of Intensity at Access to Pornography and Adolescent Sexuality. That teenagers usually access these negative content when they are alone, not around many people and in the absence of parents (Purnomo, 2014).

According to (Hilton \& Watts, 2011), a neurological study of addiction suggests that not only do the chemical changes in the brain that are known to occur at the beginning of an addiction, but the anatomy and pathological changes could also occur, resulting in hypofrontality syndrome. This syndrome included: compulsively, impulsively, and emotional. Impassivity is the root of addiction that can eventually harm if it doesn't put into the processing of the right frontal lobe. Individuals with a sexual addiction have been known to relieve their sexual impulses by means of the consumption of pornography and may experience a lot of nonphysical consequences of sexual addiction through the consumption of pornography (Reid, 2012).

Participant explained that they used pornography when alone and without their parents at home. The results of the interview participants said that the situation when using pornography is usually when they are not around many people. The previous study about The Relationship between Using Porn Sites through the Media and Sexual Behavior. The definition of sexual is behavior that arises because of sexual urges. This sexual behavior is all behavior with the opposite sex or with the same sex. That using this sexual material is for curiosity or for entertainment and is satisfied with the availability of the desired sexual material. Based on the results of interviews with participants, it started with the intention and the situation was safe, when the hours were empty or there were no lessons, when the house was quiet, and my family was all sleeping (W. P. Kurniawan, 2014).

\section{Theme 4: Impact using pornography}

The results of the interview participants said that the style or way of dressing began to change to become more attractive. The study showed that pornography is a cause of socialization, has a widespread impact on cultural beliefs about women and sexual roles (Dusra, 2017). The previous study about The Relationship of Self-Control with the Change in Behavioral Tendency of Using Porn Sites in Adolescents. One of the tasks of adolescent development is the formation of new and more mature relationships with the opposite sex, and playing an appropriate role with their sex. A teenager faces developmental tasks related to physical changes and social roles that are happening to him. The tasks of development include accepting their (changing) physical condition and utilizing them with peers of any gender, accepting their respective sexual roles (male or female) and preparing for marriage and family life (Leonardhi, 2018).

Participants said they were more attractive, and paid attention to their lifestyle. That teenagers are starting to open up to new things that are more attractive, such as dressing in a sexy or feminine way. That lifestyle is from human needs that can change depending on the times or 
someone's desire to change his lifestyle. Because teenagers are more willing to try and imitate.

The participants stated that the change in attitudes towards pornographic media referred to in this study is promiscuity with their environment, self-isolation from parents, and confining themselves in the room. The results of this study are the same as the results of the journal Mawaddah in 2017 Changes in Attitudes of Adolescent towards Using Pornography. In the journal, it is stated that the attitude of one of the most disturbing things is the problem of lazy change with learning activities, locking yourself in a room, and promiscuity. Previous study showed 3 distinct pornography-use profiles emerged: nonproblematic low- frequency pornography use (68-73\% of individuals), nonproblematic high- frequency pornography use (19- $29 \%$ of individuals), and problematic high-frequency use (3- $8 \%$ of individuals). Nonproblematic and problematic high- frequency-use groups showed differences in several constructs (ie, hypersexuality, depressive symptoms, boredom susceptibility, self-esteem, uncomfortable feelings regarding pornography, and basic psychological needs) (Tóth-király et al., 2020).

The previous study about the Effect of Pornography on Knowledge and Behavior of Sexual Attitudes in Cerbon Mandiri High School Students. That this attitude is a tendency to behave in response to changes in the environment. In support of information through interviews and observations of students at the school, it is possible that pornographic media will influence sexual behavior, including the level of knowledge and attitudes about sexuality so that adolescents can apply their attitudes and behaviors in everyday life (Media et al., 2018).

The average teenager likes to shut himself off, have promiscuity, and shut himself up. The results of the participant interview stated that the change in adolescent behavior became a more closed person and withdrew from the environment. The teenagers access pornographic sites as entertainment, curiosity, to fill their spare time, and so that they are not said to be outdated in using pornographic sites supported by gadget and wifi technology. Adolescent behavior in using pornographic sites is an activity that is formed as a result of repeated habituation. Using pornographic sites by teenagers cannot be separated from the influence of the environment which includes their peer environment, as well as the neglect of their parents. In addition, compensation for parental attention and affection in the form of material enables teenagers to routinely access pornographic sites for hours by utilizing their spare time (Anam, 2015).

Adolescent behavior is the occurrence of imitation of concern. The events in pornographic videos suggest and stimulate young people to imitate or practice what they see. That the behavior of using pornographic sites is a major factor in teenage premarital sexual behavior, such as the influence of personal friends, the environment, and lack of communication with parents (Nugroho, 2016). Perceived addiction to Internet pornography predicted psychological distress above and beyond pornography use itself and other relevant variables (e.g., socially desirable responding, neuroticism). The study revealed a relationship between perceived addiction to Internet pornography and psychological distress over time, even when controlling for baseline psychological distress and pornography use (Grubbs et al., 2015).

\section{CONCLUSION}

Based on the research results obtained from the Exploration of Experiences on Adolescents Using Pornography at Setia Budhi High School, Semarang City, at first knowing that there were two kinds of access to pornography, namely peers and the internet. The internet is what 
is often used to access pornography for teenagers. Teenagers often use the internet to access pornography from web advertisements, ads that often appear on google, timeline, and google applications. There are two responses of adolescents who access pornography, namely feelings after using pornography and feelings when using pornography that is felt by the dean, daydreaming, imagining, being very curious, afraid of being caught by parents, and there is no feeling of exaggeration. Teenagers are increasingly using pornography because of their wants and needs. This has an impact on changes in appearance, changes in attitude, changes in behavior, and cognitive changes.

\section{REFERENCES}

Ambarsari, P. I. (2018). Peran Media Dengan Konten Pornografi. Publikasi Ilmiah. http://eprints.ums.ac.id/id/eprint/70837

Anam, K. (2015). Perilaku Remaja Mengakses Situs Pornografi.

Dusra, E. (2017). Pengaruh Media Internet terhadap Perilaku Menyimpang Remaja di Sekolah Menengah Atas Negeri 1 Maros. Perintis's Health Journal, 5, 30-42. https://repositori.uin-alauddin.ac.id/5610/1/ERNA DUSRA.pdf

Grubbs, J. B., Stauner, N., Exline, J. J., Pargament, K. I., \& Lindberg, M. J. (2015). Perceived Addiction to Internet Pornography and Psychological Distress: Examining Relationships Concurrently and Over Time. Psychology of Addictive Behaviors: Journal of the Society of Psychologists in Addictive Behaviors, 29(4), 1056-1067. https://doi.org/10.1037/adb0000114

Haney, J. M. (2004). Teenagers and Pornography Addiction: Treating the Silent Epidemic. $49-52$.

Hilton, D. L., \& Watts, C. (2011). Pornography addiction: A neuroscience perspective. Surgical Neurology International, 2, 19. https://doi.org/10.4103/2152-7806.76977

Kurniawan, A. (2018). Hubungan Akses Situs Porno Dengan Persepsi Remaja Tentang Pornografi (Studi Di SMPN 3 Jombang). 63.

Kurniawan, W. P. (2014). Hubungan Antara Mengakses Situs Porno Lewat Media Internet dengan Perilaku Seksual.

Leonardhi, A. (2018). Hubungan kontrol diri dengan kecenderungan perilaku mengakses situs porno pada remaja. https://www.google.com/url?sa=t\&source=web\&rct=j\&url=http://eprints.umm.ac.id/39 233/1/skripsi.pdf\&ved=2ahUKEwiZi6TW06DoAhXOdn0KHViKAW0QFjAAegQIAx AB\&usg=AOvVaw1qee2q3PhyGJK_JTU0b_Du

Mariyati, Daulima, N. H., \& Mustikasari. (2018). Terapi Kognitif Perilaku Dan Terapi Kelompok Swabantu Untuk Menangani Ansietas Remaja Dengan Kecanduan Pornografi Cognitive Behavioural Therapy And Self Help Group For Anxiety In Adolescence With Phornography Addiction. Unissula Press, 12, 122-132.

Media, P., Pengetahuan, P. T., Dan, S., Seksual, P., Hannah, S., Primita, Y., \& Primita, H. Y. (2018). Pengaruh Media Pornografi Terhadap Pengetahuan, Sikap Dan Perilaku Seksual Pada Siswasma-Smk Mandiricirebon. OASIS : Jurnal Ilmiah Kajian Islam, 2(2), 62.

Ningsih, N. C. K. (2015). Pengaruh Sikap, Kelekatan dan Faktor Demografi Terhadap 
Perilaku Menonton Pornografi Online pada Remaja.

Nugroho, R. A. (2016). Paparan Pornografi dari Media Sosial dan Perilaku Berpacaran SMK X. http://repository.uinjkt.ac.id/dspace/bitstream/123456789/53990/1/RICHO AGUNG NUGROHO - FKIK.pdf

Pahlawan, R., \& Wijayanti, A. C. (2018). Hubungan antara Pengetahuan dan Paparan Media Massa dengan Perilaku Pacaran Remaja. Kes Mas: Jurnal Fakultas Kesehatan Masyarakat, 12(1), 60-67. https://doi.org/10.12928/kesmas.v12i1.6908

Pujiati, E., \& Handayani, D. S. (2018). Pengaruh Paparan Media Pornografi dan Teman Sebaya Terhadap Perilaku Seks Remaja Kabupaten Kudus. Jurnal Profesi Keperawatan, 5(1), 57-68.

Purnomo, Y. S. (2014). Hubungan Intensitas Akses Pornografi Di Internet Dengan Perilaku Seksual Remaja Di Smk Negeri 8 Surakarta Skripsi.

Puspitasari, A., Sakti, H., \& Kes, M. (2019). Hubungan Religiusitas Dengan Intensitas Mengakses Situs Pornografi Pada Siswa Kelas Xi Sma Hasyim Asyâ ${ }^{\mathrm{TM}}$ Ari Pekalongan. Empati, 7(4), 107-113.

Putri, Z. N., Iqsan, F., \& Aini, S. (2017). Porn Addiction And Cognitive Behavior Therapy In Young Generation. February, 1036-1042.

Reid, R. C. (2012). The Impact of Internet Pornography on Adolescents: A Review of The Impact of Internet Pornography on Adolescents : A Review of the Research. July 2015. https://doi.org/10.1080/10720162.2012.660431

Siyoto, S., Dwianggimawati, M., Mada, U. G., \& Sodik, M. A. (2018). The Effect of Pornography Accessity to Influence Sexual Behavior. December. https://doi.org/10.5958/0976-5506.2018.02062.4

Tóth-király, I., Potenza, M. N., \& Orosz, G. (2020). High-Frequency Pornography Use May Not Always Be Problematic. https://doi.org/10.1016/j.jsxm.2020.01.007

Yati, M., \& Aini, K. (2018). Studi Kasus: Dampak Tayangan Pornografi Terhadap Perubahan Psikososial Remaja. Jurnal Ilmu Dan Teknologi Kesehatan, 9(2), 64-71. https://doi.org/10.33666/jitk.v9i2.189 
Indonesian Journal of Global Health Research, Vol 3 No 1, February 2021, pp. 91 - 100 Global Health Science Group 